\title{
Some aspects of the relationship between the Freiburg School and the Austrian School
}

Citation for published version (APA):

Meijer, G. (1999). Some aspects of the relationship between the Freiburg School and the Austrian School. METEOR, Maastricht University School of Business and Economics. METEOR Research Memorandum No. 001 https://doi.org/10.26481/umamet.1999001

Document status and date:

Published: 01/01/1999

DOI:

10.26481/umamet.1999001

Document Version:

Publisher's PDF, also known as Version of record

\section{Please check the document version of this publication:}

- A submitted manuscript is the version of the article upon submission and before peer-review. There can be important differences between the submitted version and the official published version of record.

People interested in the research are advised to contact the author for the final version of the publication, or visit the DOI to the publisher's website.

- The final author version and the galley proof are versions of the publication after peer review.

- The final published version features the final layout of the paper including the volume, issue and page numbers.

Link to publication

\footnotetext{
General rights rights.

- You may freely distribute the URL identifying the publication in the public portal. please follow below link for the End User Agreement:

www.umlib.nl/taverne-license

Take down policy

If you believe that this document breaches copyright please contact us at:

repository@maastrichtuniversity.nl

providing details and we will investigate your claim.
}

Copyright and moral rights for the publications made accessible in the public portal are retained by the authors and/or other copyright owners and it is a condition of accessing publications that users recognise and abide by the legal requirements associated with these

- Users may download and print one copy of any publication from the public portal for the purpose of private study or research.

- You may not further distribute the material or use it for any profit-making activity or commercial gain

If the publication is distributed under the terms of Article $25 \mathrm{fa}$ of the Dutch Copyright Act, indicated by the "Taverne" license above, 
SOME ASPECTS OF THE RELATIONSHIP BETWEEN THE FREIBURG SCHOOL AND THE AUSTRIAN SCHOOL

Dr. Gerrit Meijer

Maastricht University

Department of Economics

P.O.Box 616

6200 MD Maastricht

The Netherlands

Tel. +31-43-388 3649/363

Fax $+31-43-3258440$

E-mail g.meijer@algec.unimaas.nl 


\section{ABSTRACT \\ Some Aspects of the Relationship between the Freiburg School and the Austrian School}

This paper is about some aspects of the interrelationship of the Freiburg School and the Austrian School. The relationships between these schools will be discussed in the field of economic theory and economic policy. No attention will be paid to the similarities and differences in the field of social philosophy and methodology.

For the Freiburg School we will concentrate on W. Eucken, F.A. Hayek and W. Röpke. For the Austrian School the following writers will be contemplated: L. Mises and F.A. Hayek. Also the connection to Schumpeter will be discussed. In the case of Hayek there is a personal union.

The paper consists of the following sections:

+ Eucken and the Austrian School.

+ Röpke and the Austrian School.

+ Some closing remarks.

The five authors who have got our special attention in trying to say something on the relationships between the Freiburg and the Austrian School took different positions in economic theory and economic policy.

Schumpeter and Mises belong to the same generation of the Austrian School. Schumpeter studied the relations between socialism, capitalism and democracry but obstained from formulating ideas on a policy to influence the developments he prophetized.

Mises staunchly defended liberalism and attacked the centrally administered economy and interventionism. He questioned whether the renewal of liberalism (by e.g. Eucken, Hayek and Röpke), for which the foundations were laid by Cannan, Knight and himself would avoid interventionism (i.e. interferences in the economic process by direct controls).

Eucken, Hayek and Röpke were looking for possibilities to influence developments. In principle the disagreement between the fundamental position of Mises and this triumvirate may be described as follows. In contrast to Mises they thought that their diagnosis of the crisis of society had to be followed by showing a way out of that crisis by the programmes of active policy they formulated. The crisis according to them was so deep and severe that they felt themselves obliged to do their utmost to turn the tide. For that reason they thought active policies were necessary, with avoidance of centrally administered economies and the kind of interventionism which Mises in their opinion with convincing arguments warned against.

J.E.L.code: B29, B31, P10, P 51 


\section{INTRODUCTION}

This paper is about some aspects of the interrelationship of the Freiburg School and the Austrian School. The relationships between these schools will be discussed in the field of economic theory and economic policy. No attention will be paid to the similarities and differences in the field of social philosophy and methodology. The original contribution of

Eucken to methodology concerns the relationship between history and theory. He was critical with regard to the historical school (Schmoller) as well as to the founder of the Austrian School (Menger).

For the Freiburg School we will concentrate on W. Eucken, F.A. Hayek and $W$. Röpke. For the Austrian School the following writers will be contemplated: L. Mises and F.A. Hayek. Also the connection to Schumpeter will be discussed. From this it shows that in the case of Hayek there is a personal union.

The paper consists of the following sections:

+ Eucken and the Austrian School

2.1. Eucken and the Freiburg School

2.2. Eucken and Mises

2.3. Eucken and Hayek

2.4. Eucken and Schumpeter

+ Röpke and the Austrian School

3.1. Life and work

3.2. Röpke and Mises

3.3. Röpke and Hayek

3.4. Röpke and Schumpeter

The final section contains some closing remarks.

\section{EUCKen AND the Austrian School}

\subsection{Eucken and the Freiburg School}

In this section a few remarks have to be made to introduce Walter Eucken and the Freiburg School. For a fuller treatment 
the reader is referred to existing literature (see Meijer 1987a, 1987b, 1988a and 1994). Walter Eucken (1891-1950) was professor of economics in Freiburg, Germany. There in the thirties originated the Freiburg or Ordo School, of which he may be regarded as the founder or head. The term Ordo School was first introduced by Hero Moeller to coin the ideas of the contributors to ORDO. Jahrbuch für die Ordnung von wirtschaft und Gesellschaft (founded by the lawyer Franz Böhm and Eucken in 1948). Contributors were among others F.A. Hayek and

W. Röpke. These two latter writers contributed regularly to ORDO, but in the strict geographical sense did not belong to the Freiburg school. There was a mutual influence between Eucken, Hayek and Röpke.

In ORDO a lot was published on problems of international economic order, but mostly in the Austrian tradition, also by Haberler and Machlup. Those ideas were already formulated in the thirties long before the founding of ORDO.

In the work of Eucken (1990, Viertes Buch; originally 1952) and implicitly also in the works of the other members of this school there are mentioned six constitutive and four regulative principles on which a competitive order (Wettbewerbsordnung) is founded. According to Eucken these six constitutive principles are: (1) stability of the monetary system; (2) open market i.e. free entry; (3) private property, also of the means of production; (4) freedom of contract, however not to destroy competition; (5) complete liability for economic actions; and (6) constancy of the policy. These six constitutive principles have to be realized simultaneously.

Apart from these constitutive principles Eucken distinguishes the regulative principles that are directed towards keeping the competitive order intact. There are four of these principles: (1) a policy to attack monopolies

(Antimonopol-politik); (2) a policy aimed at changing the distribution of incomes; (3) the fixing of minimum wages; and (4) a policy to equalize individual and social costs. 


\subsection{Eucken and Mises}

There is little evidence of a direct influence of Mises on Eucken. The most important direct influence concerns the theory of the centrally administered economy. Eucken (1959,

p. 255) thinks that the thesis of Von Mises (1922; originally $1920)$ is correct for the completely centrally administered economy. It holds for this type of centrally administered economy that there is no exchange and therefore no pricing. According to Eucken exact calculation is than impossible. For that reason the central administration encounters in the long run great difficulties. In practice the centrally administered economy is never present in its pure form, but exists always in connection with the free exchange economy. In this mixed form pricing can take place. To the extent that the exchange economy is more dominant, the above mentioned difficulties are less pronounced. Eucken builts further on Mises in his own methodological style. His own theory is based in historical reality (in particular the experiences with the centrally administered economy in the Soviet Union and Nazi-Germany). Eucken refers in this connection to two post-war works of Mises: Planned Chaos and Human Action (Eucken 1990, p.139).

Besides this directly traceable influence there is also an indirect influence of Mises on Eucken via his pupils Haberler, Hayek and Machlup. This concerns in the first place monetary theory and business cycle theory. The monetary overinvestment theory (in which monetary theory and capital and interest theory were brought together) was one of the elements in Eucken's thinking on the business cycle. This theory originated in the Austrian School through work of Böhm-Bawerk, Wicksell and Mises. Eucken himself contributed to the development of these theories from the twenties onwards in his own methodological style (see Folz 1970 and Yeager 1994). Further on here has to be mentioned the theory of international economic relations. Here is an important indirect influence of Mises via his pupils Haberler and Machlup. These theories of Austrian economists have become 
generally accepted. In the Freiburg school these ideas were elaborated by Eucken, Gestrich, Lutz, Maier, and Meyer.

In the theory of market structures and price theory there is in the case of Eucken no influence of the Austrian School (see Eucken 1959 and Meijer 1987b, 1988a). In this Eucken has affinity to Chamberlin, Robinson and Stackelberg. He integrated and corrected their work in his methodological approach. This is very important for his ideas on competition policy. Here is a distance between Mises and Eucken; but also between Eucken on the one side and Hayek and Röpke on the other. It concerns a difference in opinion on the norm for competition policy: complete (not perfect) competition versus some kind of workable competiton (Röpke 1962). Mises also disagreed with Eucken on competition policy (Röpke 1961, pp. 10, 11) .

The constitutive and regulative principles are important for the national as well as the international order. Eucken has explicitly worked out his constitutive principles for the international order (especially with regard to the monetary system, for which he was in favour of the commodity reserve standard and $100 \%$ money). In the case of the regulative principles he has not. A reason for this may be that some of the topics were not as important at that time than nowadays (environment, multi-nationals) at the international level.

In an article in ORDO entitled Staatliche Souveranität und die Ordnung der Weltwirtschaft Hans Willgerodt (1989) not only gives a review of central ideas of the Freiburg or Ordo School on international order: especially of Eucken, Hayek, Lutz and Röpke. He also asks whether the regulative principles have to be executed at the international level or whether it is sufficient that all nations follow them. He thinks this may be necessary e.g. in the case of multinationals and environment (i.e. with regard to border-crossing problems). In the same article Willgerodt shows the importance for the international economic order of all the six constitutive principles of Eucken. 


\subsection{Eucken and Hayek}

In 1960 Hayek gave an inaugural lecture at the University of Freiburg, in which he acknowledged his affinity to Eucken and the Freiburg School. There he said in his lecture called Wirtschaft, Wissenschaft und Politik (Economy, Science and Politics):

Besonders musz ich aber der persönlichen Beziehungen zu Freiburger Kollegen gedenken, die mich schon seit Jahrzehnten mit dieser Universität verbinden. ... Weitaus am wichtigsten für mich war aber meine langjährige Freundschaft, gegründet auf völlige Ubereinstimmung in theoretischen und politischen Fragen, mit dem unvergeszlichen Walter Eucken" (Hayek 1969, pp.1,2).

Eucken tried to find out which orders (e.g. market and money) have existed and how they worked in practice and to understand them theoretically. At this basis he defends the competitive order and clearly points out that spontaneous orders have to be made conform to this system (Eucken, 1990, sixth edition, p.179).

Hayek's position was that by studying the evolution of human society it would be possible to find out where the existing order had made developments that had to be corrected (for example money) and in what way, and that it would be possible to foresee where it would go wrong (e.g. his critique of Lange). But he warned against the hybris of reason and the possibility of destruction of freedom by the omnipotent totalitarian state. Therefore he prefers selective intervention by the state. That is planning for competition.

Hayek constraints conscious regulation of the order of society to the enforcement of rules that are necessary for the formation of a spontaneous order, from which the details can not be foreseen. Although a spontaneous order is thinkable without force as a rule (en)force(ment) is necessary. This is the task of government (Hayek, 1973, 1976, 1979). From this it may be concluded that as Hayek says in principle they were in full agreement. 


\subsection{Eucken and Schumpeter}

There are several important disagreements between Eucken and Schumpeter. Three of these should at least be mentioned here. With regard to the centrally administered economy Schumpeter (1961, Part III; originally 1942) thought that there are no differences in principle between the free exchange economy and the centrally administered economy. Eucken (1948 and 1990) however developed a special theory for the centrally administered economy based not on abstract theory but on historical reality).

With regard to the market structures of oligopoly and monopoly schumpeter wrote that they have dynamic advantages above perfect competition. Eucken attacks this opinion. He argues that oligopolies and monopolies infringe upon optimal equilibrium. Although there can be observed a strong growth in these sectors this is not necessarily so. However the investments partly can not be influenced by the consumers because there is no longer consumer sovereignty. Schumpeter thinks that perfect competition not only is at a disadvantage but also does not and cannot exist in reality. Eucken disagrees and observes that schumpeter's ideas in this respect have no foundation in reality, when perfect competition is redefined in complete competition (see for this discussion Eucken 1990, pp.38, 226, 239; Schumpeter 1961, chapter 8).

The most important difference is that Schumpeter studied the development of capitalist society. He observed in a positivist way the forces and contra-forces in society. He thought the development from capitalism to socialism to be inevitable because the tendencies in this direction were stronger. Eucken argues that schumpeter studied not reality but theoretical constructs of capitalism and socialism. His theories on the economic working of socialism and his theory of the cultural indeterminateness of socialism (especially that it could be combined with democracy) are not founded in reality but also theoretically untenable. In history this kind of socialism has 
never existed and will never become reality. The same can be said of the combination of socialism and democracy Schumpeter thinks possible. Eucken studied the functioning of economic order in reality and history. He was looking for a well functioning humane economy (ORDO) and how to realize this. In this effort he gave himself much trouble to show that the competitive order was not only a desirable ORDO but also a possible economic order (Ordnung); see for this discussion Eucken 1948 and 1990; Schumpeter 1961). 


\section{RÖPKE AND THE AUStRIANS}

\subsection{Life and work}

Wilhelm Röpke was born in Germany in 1899 and lectured at the Universities of Jena, Graz and Marburg. In 1933 he was dismissed by the Nazi's, who had just come into power, because of his anti-national socialist behaviour. He left for Turkey (the University of Istanbul). In 1937 he became a professor at the Institut des Hautes Etudes Internationales in Geneva. There he died in 1966.

After the First World War, in which he had to serve, he studied political sciences (Staatswissenschaften, political economy). In the twenties and early thirties he devoted himself mainly to economics.

In his contribution to the compilation of articles published at the occasion of Röpke's sixtieth birthday, Hayek (in Röpke

1959, pp. 25-28) tells us that they came into contact because they both were working on monetary and business cycle theory and the problems of international economic relations. Röpke made important contributions to all these subjects and also to public finance. In this respect he worked in the Austrian tradition.

Besides these "Austrian" influences, Röpke was influenced by the sociologist A. Rüstow (1885-1963), who just like Röpke became a professor at the University of Istanbul and did not return to Germany before 1949 and in 1950 was appointed to succeed Alfred Weber at Heidelberg (Meijer 1988b, pp.77-80). They extended neoliberalism in a sociological direction, just as Müller-Armack did. This influence is obvious already in the English translation of his book on business cycles (1936; an extended version of the German book of 1932); in his textbook on economics (first published in 1937) and in Rüstow's Appendix to Röpke's book of 1942 on international economic disintegration .

From this time onwards his publications are mainly on international economic and political relations and on the political and sociological problems of the western society. 
In this respect also there is a close parallel between Röpke and Hayek. Both change there subject more and more from theoretical economics to political problems.

During the war Röpke published his trilogy: Die Gesellschaftskrise der Gegenwart (The Social Crisis of Our Time), Civitas Humana and Internationale Ordnung, in which he elaborated his ideas on economic and social policy at the national level as well as from the international perspective. In these books the fore-mentioned influences are clearly recognizable, especially also the influence of Rüstow, who published from 1950-1957 his trilogy Ortsbestimmung der

Gegenwart.

The program of social and economic policy that Röpke advocates includes four supplementary groups of measures:

First, there have to be taken measures to create and maintain the institutions of an economic order based on competition (Wettbewerbsordnung). This is the policy of economic order (Rahmenpolitik). To this belongs a policy directed against monopolies.

Second, he wants to interfere in the economic process. This he calls the policy of the economic process (Marktpolitik). He looks for criteria for the way of interference. In the footsteps of Rüstow he is in favour of adjustment interventions. Changes in the data of the economic process often bring painfull adjustments for the economic subjects involved. Then only those interventions are acceptable that do not resist the dynamic working of the formation of prices. They have the intention to make the adjustment process less painful and quicker. The second criterion is that of compatible and non-compatible (conform and non-conform) interferences. With each measure one has to ask oneself whether the instrument used is compatible with the market economy. According to Röpke only interventions of this kind will not lead to collectivism. This position is in agreement with Mises (1929; originally 1926) and Hayek (see Hayek 1976 II, pp. 128-129 and 188). 
Third, measures, which together form the economic-social structure policy, and aim at changing the income and property distribution, the size of firms, the distribution of the population over city and country and over agriculture and industry are necessary. They concern the sociological conditions of the market economy. This means the fostering of the medium and small firms and property formation, in order to fight proletarization and massification. The policy has to be focused on dispersion of industry and deconcentration in industry. In this context he speaks of economic humanism.

According to Röpke at last a policy has to be conducted which is focused on the creation of a structure of society in which the market economy can prosper. This (the so-called Gesellschaftspolitik) is strongly neglected according to Röpke and Rüstow by the liberals of the former century. Fighting against massification and proletarization, fostering of agriculture and handicraft and dispersion of the industry are therefore necessary. Röpke and Rüstow consider this part of the measures as the most important.

From this time on Röpke's influence - also his international influence - grew very fast. His works were translated into many languages. He propagated his ideas wherever he could to influence public opinion.

Also I have to point to his endeavours to institutionalize international contacts between scientists. Together with Rüstow he attended in 1938 the Colloque Lippmann at Paris. This colloquiumm was held at the initiative of Louis Rougier, and called after the American publicist Walter Lippmann. His book The Good Society (published 1937) was the subject of discussion. After the war a meeting was held in Vevey in Switzerland. This was made possible by endeavours of Röpke. Here in April 1947 the Mont Pèlerin Society was born of which he became in the sixties, after Hayek, the second president (Hartwell, 1995).

During and after the war he (Röpke, 1947) immediately tried to influence the Allies and wrote on the German problem. His 
ideas became the background of German economic policy in 1948 . They were accepted by Erhard and Müller-Armack. When the economic policy of Erhard just after the reform was fiercely attacked by American Keynesians the Adenauer cabinet asked Röpke to write a report on German economic policy. It was entitled: Ist die deutsche Wirtschaftspolitik richtig? In this he defended the German economic policy and convinced the American government. However he was also critical of the social market economy of Germany. This appears clearly in his study of 1958: Zehn Jahre Soziale Marktwirtschaft und seine Lehren and his last book Jenseits von Angebot und Nachfrage (1958). Of special importance are his contributions to the meetings of the Aktionsgemeinschaft Soziale Marktwirtschaft (A.S.M.) (first president A. Rüstow). In these studies he explains that the situation in many aspects has changed in a favourable way after he wrote his trilogy. However the economic-social structure policy and the Gesellschaftspolitik had been neglected. The welfare state influenced by the ideas of Beveridge and Keynes is strongly attacked. He complaints about the fact that the criteria for a sound economic policy have been very often neglected or given a too large extension (this means abused).

\subsection{Röpke and Mises}

Röpke himself recognizes that he has been deeply influenced by Mises. In this respect he mentions three books by Mises: Die Gemeinwirtschaft (1922) and Nation, staat und Wirtschaft (1919) and Theorie des Geldes und der Umlaufsmittel (1912; 1924 second edition). It concerns especially the broad approach of Mises (common in continental Europe in that time) to the problems of society.

In this connection I want to pay attention to Röpke's ideas on the international economic order. He was strongly opposed to centralization in Europe and feared Fortress Europe. He was in favour of free migration (Röpke 1950, pp. 607-645). In this his experience with red and brown totalitarianism and war, 
especially during the thirties and the forties was decisive.

An important source of these ideas was according to Röpke Ludwig von Mises in his much neglected book Nation, Staat und Wirtschaft. A central idea in that book is the distinction between two categories of nationalism: the liberal or pacifist nationalism (liberale oder pazifistische Nationalismus) and the militant or imperialistic nationalism (militante oder imperialistische Nationalismus). The first is compatible with international peace, welfare and justice. This kind of nationalism is no barrier to international economic relations. This idea is also central to the thinking of Röpke. Similar ideas were written down by Lionel Robbins (1937), who was also strongly influenced by the Austrians, especially in the thirties. Another source of influence was in his case (and to some extent also in the case of Hayek) the English economist E. Cannan.

In 1942 Röpke published a book entitled International Economic Disintegration on the causes and consequences of the disintegration of the world economy in this century. He also paid attention to the question how to overcome the situation. According to Röpke in the footsteps of Mises economic nationalism was the cause of the disintegration. To overcome this situation he propagates denationalization of economic life or especially denationalization of people (Denationalisiering des Menschen). Nevertheless he thinks it a second best solution. The first best solution he thinks lies in the following direction and in this he goes (just like Robbins 1937 and Hayek 1944) a step further than Mises.

The existence side by side of souvereign states according to him is a danger to world peace, without which no world economy is possible. The liberals in the nineteenth century (and von Mises) were not sufficiently aware of this. They argued that free trade is advantageous for everybody and war is senseless and harmfull. They thought that when all states conducted a liberal policy internally as well as internationally there would not arise international conflicts. This was a serious 
misunderstanding according to Hayek, Robbins and Röpke.

The states have to render their right to conduct war (their sovereignty) to the federation. The local states are not allowed to hamper free trade. Decisions about this rest with the federal government. The federal government also looks after an uniform legal order to make the market order as effective as possible. World federalism has to be realized in stages if possible.

After the second World War particularly the problem of European economic integration was under discussion. Röpke was rather sceptic with regard to the European Community. He expected a splitting up of the so-called free world as far as Europe concerned in two blocks, namely the European Commnunity and European Free Trade Area. He feared for a disturbance of the co-operation in NATO and for an impediment to the realization of the Atlantic Community.

\subsection{Röpke and Hayek}

Röpke is sometimes considered to be conservative; in any case when compared with Hayek. However in his Constitution of Liberty (1960) Hayek never attacks Röpke and cites him only in a favourable way. In the postscript to this book Hayek explains why he is not a conservative. Reading this book and especially the postscript I think in the opinion of Hayek Röpke was far from being conservative. In his contribution to Gegen die Brandung (Against the Tide), Hayek mentions the civil courage of Röpke to discuss cherished ideas like equality and full employment, etc. Of course just like Hayek he was looking for allies in the intellectual and political battle. These were the conservatives. But Röpke although having Burke as a motto for his last book, was not a conservative. Even less so was Burke, also according to Hayek. Many conservatives especially Russell Kirk have a high esteem of Röpke. Röpke's ideas were founded however firmly in Austrian Economics.

Both Hayek and Röpke have to be given their full due for 
their work. Ever since the beginning of the industrial revolution there have been discussions on the development of society. We may mention St. Simon, Marx, Mill, Schumpeter, Sombart, and Rüstow. Röpke and Hayek shared their concern with the development of society. There were optimists and pessimists. There were those who thought society ought to be wholly restructured and that this could be done with a combination of state power and reason (science).

Hayek (1973, 1976, 1979) prefers selective intervention by the state, in the form of planning for competition. The spontaneous order may be improved by rules of reason. It is the government that has the task to do this. For that reason the necessary and sufficient conditions for the creation and preservation of the spontaneous order have always been at the centre of Hayek's research program. Therefore Hayek (see also 1960) wrote extensively on problems of economic policy, to find out which policy ought to be conducted in order not to destroy but if possible to improve the spontaneous order. This is exactly the same attitude as we find in Röpke.

\section{4 Röpke and Schumpeter}

There are important parallels in thinking between Röpke and Schumpeter (Röpke 1959, pp.354-362; Schumpeter 1961). The analysis of capitalism is similar and they both were impressed by the degeneration and the erosion of the foundations of capitalism. They are however in full disagreement on the desirability and possibility of the centrally administered economy; economically as well as politically. Whereas

Schumpeter constrained himself to observing with crossed arms, Röpke was searching for a third way (as described in 3.1) and fought against the totalitarian centrally administered systems (collectivism) and capitalism.

\section{Closing Remarks}

A few remarks may be made at the end of this paper. The five authors who have got our special attention in trying to say 
something on the relationships between the Freiburg and the Austrian School took different positions in economic theory and economic policy.

Schumpeter and Mises belong to the same generation of the Austrian School. Schumpeter studied the relations between socialism, capitalism and democracry but obstained from formulating ideas on a policy to influence the developments he prophetized.

Mises staunchly defended liberalism and attacked the centrally administered economy and interventionism. He (Mises 1959, pp.591-603) questioned whether the renewal of liberalism, for which the foundations were laid by Cannan, Knight and himself would avoid interventionism. He (Mises 1929) distinguished Preistaxen and Ordnungstaxen. Preistaxen had to be avoided. His critique on Eucken's ideas on competition policy originates from this source. He thinks that this is a policy that will have to use not only ordnungstaxen but also Preistaxen.

Eucken, Hayek and Röpke were looking for possibilities to influence developments. In principle the disagreement between the fundamental position of Mises and this triumvirate may be described as follows. In contrast to Mises they thought that their diagnosis of the crisis of society had to be followed by showing a way out of that crisis by the programmes of active policy they formulated. The crisis according to them was so deep and severe that they felt themselves obliged to do their utmost to turn the tide. For that reason they thought active policies were necessary, with avoidance of centrally administered economies and the kind of interventionism which Mises in their opinion with convincing arguments warned against. 
Fout! Bladwijzer niet gedefinier 


\section{REFERENCES}

Eucken, W. (1948) On the Theory of the Centrally Administered Economy: An Analysis of the German Experiment, Economica Vol. XV N.S., May and August, pp. 79-100 and pp. 173-193. Eucken, W. $(1959,7)$ Die Grundlagen der Nationalökonomie, Berlin: Springer Verlag.

Eucken, W. $(1990,6)$ Grundsätze der Wirtschaftspolitik, Tübingen: Mohr/Siebeck.

Folz, W.J. (1970) Das geldtheoretische und geldpolitische Werk Walter Euckens, Berlin: Duncker und Humblot.

Hartwell, R.M. (1995) A History of the Mont Pelerin Society, Indianapolis: Liberty Fund.

Hayek, F.A. (1960) The Constitution of Liberty, London/

Chicago: University of Chicago Press.

Hayek, F.A. (1944, 1961), The Road to Serfdom, Chicago/London: University of Chicago Press.

Hayek, F.A. (1969) Freiburger Studien, Tübingen: Mohr/Siebeck. Hayek, F.A. (1973, 1976, 1979) Law, Legislation and Liberty, Vol.I, II, III. Chicago/London: University of Chicago Press. Meijer, G. (1987a) The History of Neoliberalism: A General View and Developments in Several Countries, Rivista

Internazionale di Scienza Economiche e Commerciali, Vol.34, pp. 577-591.

Meijer, G. (1987b) The History of Neoliberalism: Affinity to some Developments in Germany, Festschrift in Honour of Anghel N. Rugina, Part II, International Journal of Social Economics, Vol.14, Nos 7/8/9, pp.142-155

Meijer, G. (1988a) Het neoliberalisme. Neoliberalen over economische orde en economische theorie, Assen/Maastricht: Van Gorcum.

Meijer, G. (1988b) Alexander Rüstow Commemorated, HES Bulletin Vol.10, No.1, pp.77-80.

Meijer, G. ed. (1994) The Institutional Basis of Market Economies. Walter Eucken's Contribution to Economics. Special issue of The Journal of Economic Studies, Vol. 21, 
Nr. 4.

Mises, L. $(1912 ; 1924,2)$ Theorie des Geldes und der

Umlaufsmittel, München/Leipzig: Duncker und Humblot.

Translated in English: The Theory of Money and Credit,

Indianapolis: Liberty Press 1981.

Mises, L. (1919) Nation, Staat und Wirtschaft, Wien/Leipzig:

Manzsche Verlags- und Universitäts-Buchhandlung.

Translated by L. Yeager (1983) under the title Nation,

State and

Economy, New York/London: New York University Press.

Mises, L. (1922) Die Gemeinwirtschaft, Jena: G.Fischer.

Translated in English: Socialism, Indianapolis: Liberty

Press 1981.

Mises, L. (1927) Liberalismus, Jena: G.Fischer.

Mises, L. (1929) Kritik des Interventionismus, Jena:

G.Fischer.

Mises, L. (1947) Planned Chaos, Irvington on Hudson, N.Y.:

The Foundation for Economic Eduation, Inc.

Mises, L. (1949) Human Action, New Haven: Yale University

Press.

Mises, L. (1959) Liberalismus, Handwörterbuch der

Sozialwissenschaften Bd 6, Göttingen 1959, pp. 591-603

(together with F.A. Hayek).

Robbins, L. (1937) International Order and Economic Planning,

London: MacMillan.

Röpke, W. (1932) Krise und Konjunktur, Leipzig: Quelle und

Meyer.

Röpke, W. (1936) Crises and Cycles, London: W.Hodge and Co.

Röpke, W. (1937, 1954,7) Die Lehre von der Wirtschaft,

Erlenbach-Zürich: E. Rentsch.

Röpke, W. (1942) International Economic Disintegration,

London: MacMillan. With an appendix of A.Rüstow: The General

Sociological Causes of the Economic Disintegration and

Possibilities of Reconstruction.

Röpke, W. (1943)(4) Die Gesellschaftskrise der Gegenwart, 
Erlenbach-Zürich: E.Rentsch.

Röpke, W. (1945) Internationale Ordnung, Erlenbach-Zürich:

E.Rentsch.

Röpke, W. (1946) (2) Civitas Humana, Erlenbach-Zürich:

E.Rentsch.

Röpke, W. (1947) The Solution of the German Problem, New York: G.P.Putnam's Sons.

Röpke, W. (1950) Ist die deutsche Wirtschaftspolitik richtig?

Analyse und Kritik, Stuttgart-Köln: W.Kohlhammer.

Röpke, W. (1950) Barriers to Immigration, in Twentieth Century

Economic Thought, Glenn Hoover (ed.), New York: The

Philosophical Library, Inc., pp.607-645.

Röpke, W. (1958) Ein Jahrzehnt Soziale Marktwirtschaft in

Deutschland und seine Lehren, Schriftenreihe der ASM, Heft

1, Köln: Verlag für Politik und Wirtschaft.

Röpke, W., (1958) Jenseits von Angebot und Nachfrage,

Erlenbach-Zürich-Stuttgart: E.Rentsch-Verlag.

Röpke, W. (1959) Gegen die Brandung. Zeugnisse eines

Gelehrtenlebens unserer Zeit. Gesammelt und herausgegeben

von A.Hunold, Erlenbach-Zürich: E.Rentsch-Verlag.

Röpke, W. (1961) Blätter der Erinnerung an Walter Eucken, ORDO XII.

Röpke, W. (1962) Wettbewerb II in Handwörterbuch der

Sozialwissenschaften Bd 12, Göttingen.

Rüstow, A. (1950)(2) Das Versagen des Wirtschaftsliberalismus

als religionsgeschichtliches Problem, Zürich/Godesberg:

H. Küpper .

Rüstow, A. $(1950,1952,1957)$ Ortsbestimmung der Gegenwart,

Erlenbach-Zürich-Stuttgart: E.Rentsch.

Schumpeter, J.A. (1942, 1961, fourth edition) Capitalism,

Socialism and Democracy, London: Allen and Unwin.

Willgerodt, H. (1989) Staatliche Souveränität und die Ordnung der Weltwirtschaft, in ORDO 41.

Yeager, L.B. (1994) Eucken on Capital and Interest, in

G.Meijer ed. (1994), pp. 61-75. 
Fout! Bladwijzer niet gedefinier 
Fout! Bladwijzer niet gedefinier 